\title{
INVESTIGATION OF THE INFLUENCE OF HYDROGEL AMENDMENT ON THE RETENTION CAPACITIES OF GREEN ROOFS
}

\author{
BADANIE WPLYWU DODATKU HYDROŻELU \\ NA ZDOLNOŚCI RETENCYJNE ZIELONYCH DACHÓW
}

\begin{abstract}
Progressive economic development as well as urbanisation influence the characteristics of the stormwater runoff. Progressive sealing of drainage basin surface prompts the decrease of rainwater infiltration, thus increasing the runoff intensity. This results in an increase of flood risk. Thus, in urban areas the sustainable urban drainage systems (SUDS) are used in addition to the traditional sewer systems. The examples of SUDS strategy are, inter alia, the roofs covered with vegetation (the green roofs). The paper presents the results of research of retention capacities of 4 diverse green roof models with following growing media: (1) the typical green roof substrate without any additions, (2) the substrate with addition of about $1 \%$ by weight of hydrogel (the cross-linked potassium polyacrylate), (3) the substrate with addition of about $0.25 \%$ by weight of hydrogel, (4) the substrate with addition of expanded clay and perlite. The models did not have the vegetation layers in order to explore only the retention capacities of drainage layers and substrates. The aim of the first part of research was to investigate the retention capacities of green roof models after 1, 2, 6, 8 and 10 antecedent dry days. In the case of 1 and 2 antecedent dry days the best medium retention capacity had green roof model 2 (with substrate with addition of $1 \%$ by weight of hydrogel), and the weakest medium retention capacity had green roof model 1 (without any additions). In the cases of precipitations which occurred after 6 as well as 8 and 10 antecedent dry days the best retention capacity had green roof model 3 (with addition of about $0.25 \%$ by weight of hydrogel). The weakest retention capacity had in these cases green roof model 4 (with addition of expanded clay and perlite). The aim of the second part of research described in the paper was to investigate the retention capacities of green roof models during precipitations that occurred after long antecedent dry periods of time (34, 59 and 106 antecedent dry days). The substrates and drainage layers were air-dry directly before precipitations. The best retention capacity had in this case green roof model 3 (with the substrate with addition of about $0.25 \%$ by weight of hydrogel). The second largest retention capacity had model 2 (with the substrate with addition of about $1 \%$ by weight of hydrogel). The definitely weakest retention capacity had model 4 containing the substrate with addition of expanded clay and perlite. The results may indicate that the efficacy of hydrogel decreased over time probably due to its decay under the influence of solar radiation.
\end{abstract}

Keywords: green roof, retention capacity, stormwater management, substrate, hydrogel

\section{Introduction}

The effect of urbanisation is a dense urban development and the related increase of the area of impermeable surfaces [1-3]. This leads to the creation of barriers for natural

\footnotetext{
${ }^{1}$ Institute of Environmental Engineering, Faculty of Infrastructure and Environment, Czestochowa University of Technology, ul. Brzeźnicka 60A, 42-200 Czestochowa, phone +48 343250917

*Corresponding author: ideska@ is.pcz.czest.pl
} 
hydrological processes such as retention and infiltration of stormwater [3]. The infiltration intensity decreases, and in consequence, the stormwater runoff increases. This in turn influences the surrounding urban environment and increases the risk of flooding from sewers in urban areas [1]. Additionally the decrease of infiltration intensity leads to the degradation of groundwater resources [2].

In the urban areas, surface runoff comprises up to about $55 \%$ of stormwater, whereas runoff in the undeveloped areas comprises only about $10 \%$ of precipitation. At the natural conditions about $40 \%$ of rainwater evaporates and can return into the atmosphere, whereas in the urbanized areas only about $30 \%$ of rainwater is the subject to evaporation [4].

The increase of the area of sealed surfaces in the urban areas leads to the increase of flood risk. The increase of the risk of flood in the summer is caused by the intensive rains, whereas flood risk in the winter and spring is caused by melting of snow and ice [5].

There is a need for application of such solutions that can support the operation of traditional drainage systems [3]. Therefore, in urbanized areas in addition to the traditional sewer systems, more and more frequently are used the ecological best management practices - BMPs (term used in USA and Canada) or sustainable urban drainage systems SUDS (term used elsewhere) [1], that are the part of low-impact development (LID) principles $[6,7]$. These LID principles and strategy comprises approaches and practices which focuses are to reduce both the surface runoff and the load of pollutants in stormwater overland flow [7]. These techniques manage water at the source and prevent or reduce the impact of development on surface water and groundwater [7].

SUDS comprise such solutions as: stormwater infiltration systems [8], stormwater ponds/retention basins [1, 5], retention-infiltration reservoirs [9], infiltration basins and trenches, reducing of share of impermeable surfaces, especially in the urban areas [10]. Other examples of SUDS are bioretention systems, rain gardens and green roofs [11].

Green roofs, also referred to as vegetated roofs and ecoroofs are layered roofs covered with vegetation and growing medium $[12,13]$. Green roofs can be typically divided into three main categories: intensive, simple intensive (semi-intensive), and extensive green roofs $[13,14]$. Intensive green roofs have mostly deep substrate layer supporting bigger plants (e.g. trees, bushes). For this reason, they require maintenance such as: watering, fertilizing, weeding etc.) [13]. Simple intensive green roofs also require maintenance, but the plants are not so demanding, like in the case of intensive green roofs. The plants overgrowing simple intensive roofs are for example lawns and ground covering plantations. Then the extensive green roofs typically do not require the maintenance. The types of plants overgrowing these roofs are: succulents, herbs, grasses, mosses etc. [13].

Green roofs provide many environmental ecologic and economic benefits in comparison to the conventional roofs $[13,15,16]$. Vegetated roofs may reduce effect of urban heat island in cities [17]. They contribute to the temperature reduction around buildings and thereupon improve the efficiency of HVAC systems (heating, ventilation and air conditioning systems) and photovoltaic panels (PV panels) [18, 19]. Combination of green roofs and solar photovoltaic systems can have a positive effect on their effectiveness by both shading and cooling effects. Temperature of vegetated roof surface (especially soil temperature) can be reduced from the PV panels shading and, on the other hand, higher power output of PV panels can be achieved due to the green roof cooling effect [19].

Green roofs reduce energy consumption in buildings with poor insulation values in hot as well as in temperate and cold climates, due to the diminished need for cooling in summer 
and heating in winter [20]. Therefore they are an energy-efficient solution for a wide range of European countries [18].

Green roofs improve biodiversity in cities due to creation habitats for diverse plants and animals $[17,21]$. A development of the infrastructure of artificial green zones in urban areas plays an important role in the preservation of biological diversity [22].

The vegetated roofs can reduce air pollution [23] in urban areas. They may lead to significant sound reduction in cities [24]. Other very important reason for establishment of green roofs is their aesthetics that cannot be overestimated in the urban areas [13].

However, above all, green roofs play an important role in modern sustainable urban drainage due to their ability to delay and reduction of stormwater runoff [25], and thus lower risk of floods in urban areas $[1,26]$. High intensity of evapotranspiration from green roofs significantly reduces the annual surface runoff to less than the half of the precipitation volume $[25,26]$.

The retention capacity of green roofs is influenced, among other things, by the roof type (intensive, semiintensive, extensive), substrate thickness as well as green roof slope $[27,28]$. Green roof slope may impact the runoff retention quantities. When the roof slope increases, the retention capacity decreases [27]. The best rainfall-retention capability (up to $70 \%$ ) have the intensive green roofs. The retention capacity depends on green roof structure (the amount and depths of layers), the climatic conditions and amount of precipitation [28].

Many aspects of green roof technology are not still fully investigated. Probably one of the most important components of green roofs are the substrates which are covered with appropriate vegetation [29]. The substrate acts as artificial soil for plant growth providing nutrients and moisture and forming physical support to plants. On the other hand substrate should be suitably light in order to not overload the building structure, it should be aeratable, chemically stable, permeable, and able to drain the rainwater freely to ventilate the roots [29].

One of green roof substrate modifications should be the superabsorbent polymers (SAPs) amendment [30]. The examples of SAPs are, among other things, polyacrylamide or polyacrylate hydrogels. One of polyacrylate hydrogels is the cross-linked potassium polyacrylate. SAPs act like "artificial humus". These substances are hydrophilic and contain carboxylic groups [31]. The most important property of SAPs (e.g. polyacrylamide or polyacrylate hydrogels) is their absorption capacity for water that depends among others on the cross-linking ratio (the molar ratio of cross-linker to monomers) and the ionization degree (parameter influenced by the ionic group concentration) [31]. Superabsorbent polymers can increase the plant available water in green roof substrate and thereby enable the plants to survive longer under water stress [30,32], especially in the case of extensive roofs [30].

The objective of the experiments described in this paper was to investigate the influence of hydrogel, expanded clay and perlite amendment on the retention capacities of 4 green roof models with following substrates: (1) the typical green roof substrate, (2) the substrate with addition of about $1 \%$ by weight of hydrogel (cross-linked potassium polyacrylate), (3) the substrate with addition of about $0.25 \%$ by weight of hydrogel and (4) the substrate with addition of expanded clay and perlite. 


\section{Materials and methods}

The investigations of the influence of hydrogel amendment on the retention capacity of green roofs were conducted with use of 4 garden trays made from recycled polypropylene with internal dimensions $55.7 \mathrm{~cm}$ x $55.7 \mathrm{~cm} \times 7 \mathrm{~cm}$ (Fig. 1). In the bottom of each tray (at the right lower corner) was drilled the hole and installed the pipe for outflow of the excess of water. On the bottom of each tray the drainage element Floradrain FD 25 (a height of $25 \mathrm{~mm}$ ) was placed that was scrupulously docked for the internal tray dimensions. On each drainage element the filter sheet $S F(70 \mathrm{~cm} \times 70 \mathrm{~cm})$ was spread. In each tray exactly $10 \mathrm{dm}^{3}$ of respective substrate was placed directly on the filter sheet. The thickness of green roof substrate in each tray was reasonably uniform and amounted to about $3.2 \mathrm{~cm}$. The surface of each tray amounted to about $31 \mathrm{dm}^{2}$. The investigations of retention capacities of green roof substrates were conducted with use of 4 substrates described in Table 1 . In the models were not applied the vegetation layers in order to explore only the retention capacities of substrates and drainage layers. The slope of green roof models amounted to $5 \%$.

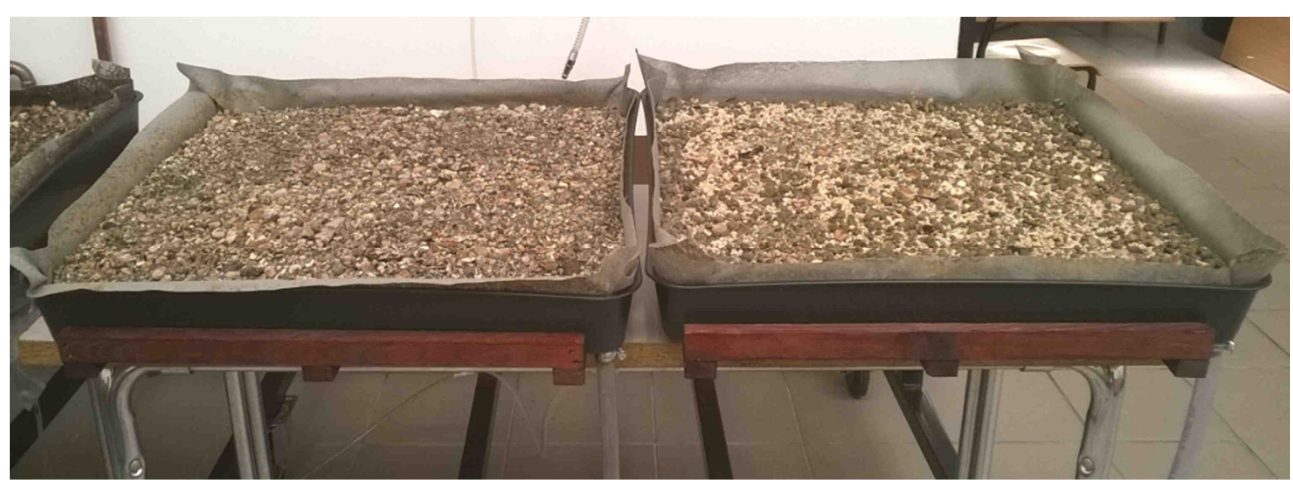

Fig. 1. The experimental set-up. The green roof models created on the garden trays. Model 3 - substrate with addition of about $0.25 \%$ by weight of hydrogel (on the left) and Model 4 - substrate with addition of expanded clay and perlite (on the right)

Properties of substrates used in the experiments

Table 1

\begin{tabular}{|c|c|c|c|}
\hline $\begin{array}{c}\text { No. of green roof } \\
\text { model }\end{array}$ & Substrate composition & $\begin{array}{c}\text { Substrate density } \\
{\left[\mathbf{k g} \cdot \mathbf{~ m}^{-3}\right]}\end{array}$ & $\begin{array}{c}\text { Substrate } \\
\text { mass [kg] }\end{array}$ \\
\hline Model 1 & Substrate "Roof Garden" - 12.120 kg & $1212 \pm 12^{*}$ & 12.120 \\
\hline Model 2 & $\begin{array}{c}\text { Substrate "Roof Garden" - 12.000 kg } \\
\text { Hydrogel - 0.120 kg }\end{array}$ & $1212 \pm 12^{*}$ & 12.120 \\
\hline Model 3 & $\begin{array}{c}\text { Substrate "Roof Garden" - 12.090 kg } \\
\text { Hydrogel - 0.030 kg }\end{array}$ & $1212 \pm 12^{*}$ & 7.625 \\
\hline Model 4 & $\begin{array}{c}\text { Substrate "Roof Garden" - 6.630 kg } \\
\text { Expanded clay - 0.597 kg } \\
\text { Perlite - 0.398 kg }\end{array}$ & $762 \pm 41^{*}$ & \\
\hline
\end{tabular}

* - SD (standard deviation)

As a simulation of a precipitation the specified volume of water was evenly spilled on each substrate surface on trays. The excess of water that was not stored on green roof 
models (the drained water) was collected in the bottles and measured with use of graduated cylinders. The volume of water stored on each model was established as the difference between the volume of precipitation and the volume of drained water.

The experiments were carried out in 2 stages: (1) investigations of the retention capacities of moist green roof models, during precipitations that occurred after 1, 2, 6, 8 and 10 antecedent dry days, (2) investigations of the retention capacities of relatively dry green roof models (the air dried substrates with the average gravimetric moisture of $4.86 \pm 1.57 \%)$.

The experiments were carried out in laboratory conditions. Main part of experiments (stage 1) was conducted from 21.05.2015 to 31.07.2015. Measurements of stage 2 were conducted after 04.09.2015.

The experimental setup was placed directly under the roof skylight so the substrate surfaces were appropriately sun-filled. The air temperature during stage 1 at the maximum insolation (from 11.00 am to $3.00 \mathrm{pm}$ ) was $30.1-41.4{ }^{\circ} \mathrm{C}$. The minimum air temperature (reached at night) amounted to $25.2{ }^{\circ} \mathrm{C}$. The air humidity during stage 1 ranged from 27 to $58 \%$.

\section{Results and discussion}

\section{Investigations of the retention capacities of moist green roof models}

Figures 2-4 show the volumes of rainwater stored on green roof models during simulated precipitations which occurred after 1, 2, 6, 8 and 10 antecedent dry days.

Averaged results for very short dry periods - 1 and 2 antecedent dry days - are presented in the Figure 2.

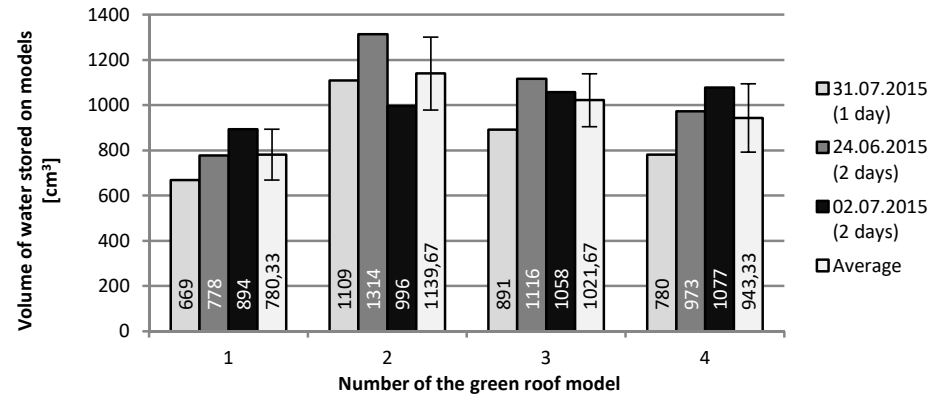

Fig. 2. Volume of water stored on green roof models during precipitations occurred after 1 and 2 antecedent dry days

The results presented in the Figure 2 show that the best medium retention capacity in this case had the Model 2 (substrate with addition of about $1 \%$ by weight of hydrogel). The second largest medium retention capacity had the Model 3 (substrate with addition of about $0.25 \%$ by weight of hydrogel), third largest value of medium retention capacity had model 4 (substrate with admixture of perlite and expanded clay), and the weakest medium retention capacity had the Model 1 (substrate without any additions). The results show that greatest amount of water stored during the alone measurement was reported for Model 2 (the precipitation that occurred on 24.06.2015). Note that the volume of water stored on 
02.07.2015 by models with substrate containing the admixture of hydrogel (especially in the case of Model 2) relatively decreased compared to the models that do not contain the superabsorbent addition This can mean that the efficacy of hydrogel decreased over time probably due to its decay under the influence of solar radiation.

Averaged results obtained for precipitations that occurred after 6 antecedent dry days are presented in Figure 3.

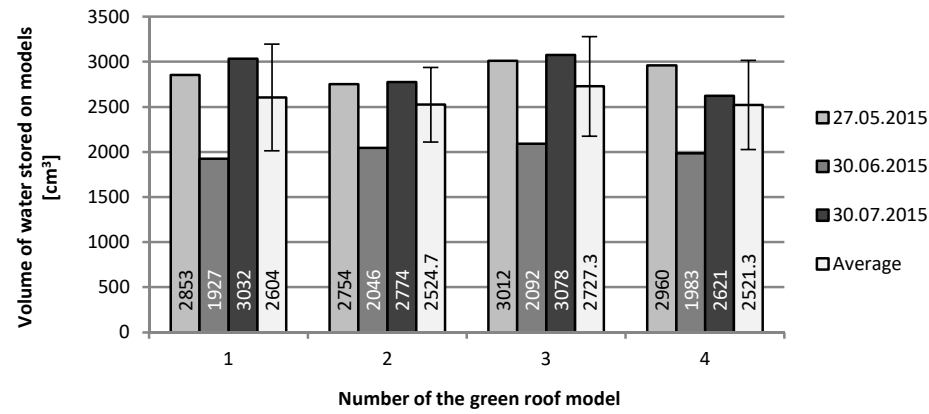

Fig. 3. Volume of water stored on green roof models during precipitations that occurred after 6 antecedent dry days

Results presented in the Figure 3 show that the greatest medium volume of water was stored in this case on Model 3 (the substrate with addition of about $0.25 \%$ by weight of hydrogel). The second largest medium retention capacity had Model 1 (the substrate without any additions). The weakest medium retention capacity had Model 4 (the substrate with addition of porous materials - expanded clay and perlite), but the medium amounts of stored water in the case of Models 2 and 4 were very similar. Regarding the single measurements, in each case the best retention capacity had Model 3. Results obtained for remaining green roof models (1,2 and 4) were somewhat disparate.

Results obtained for precipitations that occurred after 8 and 10 antecedent dry days are shown in Figure 4.

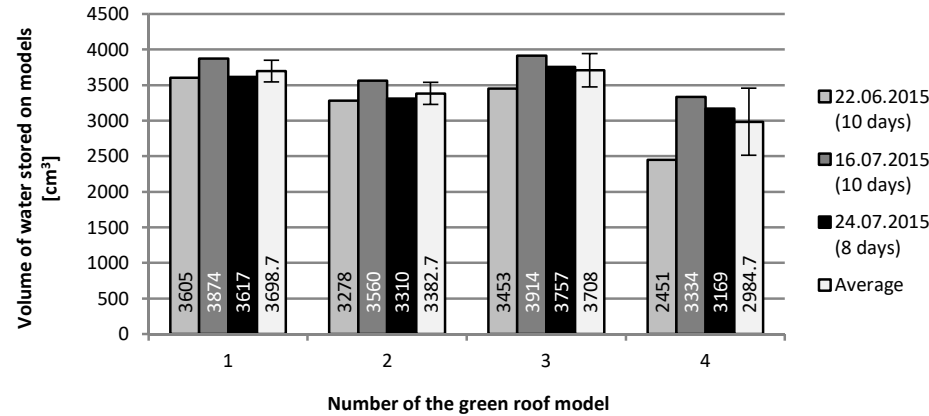

Fig. 4. Volume of water stored on green roof models during precipitations that occurred after 8 and 10 antecedent dry days 
It was decided to combine the results of investigations conducted after 8 and 10 antecedent dry days because these results were relatively similar (e.g. in the case of precipitations occurred on 22.06.2015 and 24.07.2015 for Models 1 and 2). Additionally, the results of investigations conducted after 8 antecedent dry days were in the range of results obtained after 10 dry days (e.g. in the case of Models 3 and 4). It should be noted that volumes of water stored on green roof models during precipitation occurred after 8 antecedent dry days were close or even greater from average results obtained in the case of 10 antecedent dry days. It can be stated that the greater role played in this case the air temperature in the laboratory and not the amount of days.

Averaged volumes of water stored on green roof models after 8 and 10 dry days (Fig. 4) show that the best retention capacity had in this case Model 3 (substrate with addition of about $0.25 \%$ by weight of hydrogel). The second largest medium retention capacity had Model 1 (substrate without any additions). Definitely the weakest medium retention capacity had in this instance Model 4 (the substrate with addition of expanded clay and perlite). It should be noted that the results obtained for all models were to a great extent convergent.

\section{Investigations of the retention capacities of relatively dry green roof models}

Figure 5 shows the volumes of water stored on relatively dry layers of green roof models (the precipitations which occurred after 34, 59 and 106 antecedent dry days).

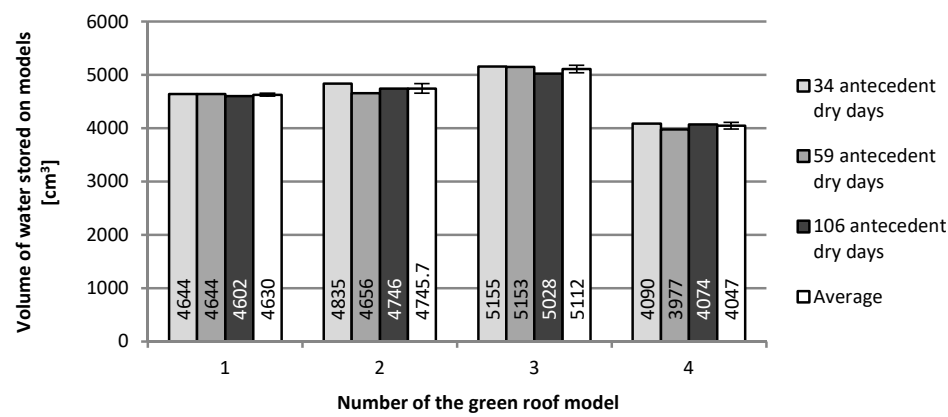

Fig. 5. Volume of water stored on green roof models during precipitations occurred after 34, 59 and 106 antecedent dry days

Results presented in the Figure 5 show that in the case of each precipitation the best retention capacity had the Model 3 (substrate with addition of about $0.25 \%$ by weight of hydrogel). The second largest retention capacity had the Model 2 (substrate with addition of about $1 \%$ by weight of hydrogel). Definitely the weakest retention capacity had the Model 4 (substrate containing the addition of expanded clay and perlite). It can be concluded that the volumes of water stored on particular Models during precipitations that occurred after 34 and 59 days are similar, especially in the case of Model 1 and Model 3.

The obtained results show that the substrate amendment with hydrogel, as well as highly porous materials (e.g. expanded clay and perlite) influenced the retention capacities of green roofs. The length of antecedent dry period was strongly correlated with the substrate water content and degree of dryness of other green roof model elements due to the 
relatively stable conditions prevailing in the laboratory in the period in which the investigations were conducted (e.g. similar daily temperature and humidity changes). It should be noted that this length of antecedent dry period has determined whether the influence of additives was positive or negative. The results indicate that the relatively low amount of hydrogel addition can positively influence the substrate retention capacity. In turn too large amount of hydrogel addition can have a disadvantageous impact on the retention capacity of green roof substrate.

The results described in the current paper show that the efficacy of hydrogel decreased noticeably over time probably due to its decay under the influence of solar radiation. This decrease was relatively fast, especially at the beginning of investigations. Likewise, Savi et al. [32] reported the decrease in the effectiveness of hydrogel observed after about 5 months from the green roof model establishment. However, in the case of their research were used vegetation and thicker substrate layers.

\section{Conclusions}

1. In the case of precipitations that occurred after 1 and 2 antecedent dry days the best average retention capacity had Model 2 with substrate containing admixture of $1 \%$ by weight of hydrogel. The weakest average retention capacity had Model 1 with substrate without any additions.

2. In the case of precipitations that occurred after 6 antecedent dry days the best medium retention capacity had Model 3 with substrate containing about $0.25 \%$ by weight of hydrogel. The weakest medium retention capacity had Model 4 with substrate containing expanded clay and perlite, but averaged amounts of water stored on Models 4 and 2 were very similar.

3. Averaged results obtained in the case of precipitations which occurred after 8 and 10 antecedent dry days show that the greatest medium volume of water was stored on Model 3 with substrate containing about $0.25 \%$ by weight of hydrogel. Definitely the weakest medium retention capacity had in this case Model 4 with substrate containing the addition of expanded clay and perlite.

4. In the cases of precipitations that occurred after long antecedent dry periods: after 34, 63 and 106 antecedent dry days (the layers of models were air dried) the best retention capacity had every time Model 3 with substrate containing about $0.25 \%$ by weight of hydrogel. The second largest retention capacity had Model 1 with substrate without any additions. The weakest retention capacity had in this case Model 4 with substrate containing expanded clay and perlite.

5. Obtained results show that the hydrogel amendment influences the retention capacity of green roof substrates. However it should be noted that results accomplished in the case of the substrate with addition of $0.25 \%$ by weight of hydrogel (Model 3) are predominantly better than that for the substrate with addition of about $1 \%$ by weight of hydrogel (Model 2), especially in the case of longer antecedent dry periods. This may mean that too large addition of the hydrogel can have an unfavorably impact on the retention capacity of green roof substrates.

6. Results show that the admixture of hydrogel as well as the addition of the lightweight porous materials e.g. expanded clay and perlite may have a positively impact on the retention capacity of green roof substrates especially in the case of very short antecedent dry periods (e.g. 1 or 2 antecedent dry days). 


\title{
Acknowledgements
}

\author{
The work was financially supported by BS-PB/401/306/11.
}

\section{References}

[1] Czemiel-Berndtsson, J. Green roof performance towards management of runoff water quantity and quality: a review. Ecol Eng. 2010;36:351-360. DOI: 10.1016/j.ecoleng.2009.12.014.

[2] Burszta-Adamiak E. Analysis of the retention capacity of green roofs. J Water Land Dev. 2012;16(I-IV):3-9. http://www.itp.edu.pl/wydawnictwo/journal/16_2012_I_VI/artykuly/ Burszta\%20Adamiak.pdf.

[3] Burszta-Adamiak E, Mrowiec M. Modelling of Green roofs' hydrologic performance using EPA's SWMM. Water Sci Technol. 2013;68(1):36-42. DOI: 10.2166/wst.2013.219.

[4] USEPA. Protecting Water Quality from Urban Runoff, EPA 841-F-03-003, February 2003. https://www.epa.gov/sites/production/files/2015-10/documents/nps_urban-facts_final.pdf.

[5] Malmur R. Transfer reservoir as a new solution for transfer of stormwater to water receivers. ASEE17. E3S Web Conf. 2017;22:00110. DOI: 10.1051/e3sconf/20172200110.

[6] Fletcher TD, Shuster W, Hunt WF, Ashley R, Butler D, Arthur S, et al. SUDS, LID, BMPs, WSUD and more - The evolution and application of terminology surrounding urban drainage. Urban Water J. 2015;12(7):3-20. DOI: 10.1080/1573062X.2014.916314.

[7] USEPA. Reducing Stormwater Costs through Low Impact Development (LID) Strategies and Practices, EPA 841-F-07-006, December 2007. http://www.nrc.gov/docs/ML1102/ML110270042.pdf.

[8] Ociepa E. Sposoby ograniczenia niekorzystnego wpływu zrzutu ścieków opadowych. (Ways of restricting the harmful influence of run-off wastewater). Chem Dydakt Ekol Metrol. 2011;16(1-2):47-50. http://tchie.uni.opole.pl/CDEM11_1-2/CDEM2011_1-2.pdf.

[9] Mrowiec M. Wyznaczanie objętości zbiorników infiltracyjnych z zastosowaniem wzorów IDF. (Estimation of required storage volume for retention reservoirs using IDF relationships). Inż Ochr Środ. 2011;14(1):73-86. https://is.pcz.pl/static/pdf/2011/zeszyt1/2011_1_7-Mrowiec.pdf.

[10] Mrowiec M. Road runoff management using improved infiltration ponds. Transp Res Proc. 2016;14:2659-2667. DOI: 10.1016/j.trpro.2016.05.435.

[11] Feng Y, Burian S, Pomeroy C. Potential of green infrastructure to restore predevelopment water budget of a semi-arid urban catchment. J Hydrol. 2016;542:744-755. DOI: 10.1016/j.jhydrol.2016.09.044.

[12] Johannessen BG, Muthanna TM, Braskerud BC. Detention and retention behavior of four extensive green roofs in three nordic climate zones. Water. 2018;10(6):671. DOI: 10.3390/w10060671.

[13] Czemiel-Berndtsson J, Bengtsson L, Jinno K. Runoff water quality from intensive and extensive vegetated roofs. Ecol Eng. 2009;35:369-380. DOI: 10.1016/j.ecoleng.2008.09.020.

[14] Breuning J, Yanders AC. Introduction to the FLL Guidelines for the Planning, Construction and Maintenance of Green Roofing. 2008 Edition of the Green Roofing Guideline. Green Roof Service LCC. 2012. http://www.greenrooftechnology.com/fll-green-roof-guideline.

[15] Shafique M, Kim R, Rafiq M. Green roof benefits, opportunities and challenges - A review. Renew Sustain Energy Rev. 2018;90:757-773. DOI: 10.1016/j.rser.2018.04.006.

[16] Grant G, Engelback L, Nicholson B, Gedge D, Frith M, Harvey P. Green roofs: their existing status and potential for conserving biodiversity in urban areas. English Nature. Research Report No. 498. 2003. http://publications.naturalengland.org.uk/file/132021.

[17] Vijayaraghavan K, Joshi UM, Balasubramanian R. A field study to evaluate runoff quality from green roofs. Water Res. 2012;46:1337-1345. DOI: 10.1016/j.watres.2011.12.050.

[18] Jaffal I, Ouldboukhitine SA, Belarbi R. A comprehensive study of the impact of green roofs on building energy performance. Renew Energy. 2012;43:157-164. DOI: 10.1016/j.renene.2011.12.004.

[19] Hui SCM, Chan SC. Integration of green roof and solar photovoltaic systems. Proceedings of Joint Symposium 2011: Integrated Building Design in the New Era of Sustainability. Kowloon. Hong Kong; 2011. http://web.hku.hk/ cmhui/JS-2011-samhui_fullpaper01.pdf.

[20] Castleton HF, Stovin V, Beck SBM, Davison JB. Green roofs; building energy savings and the potential for retrofit. Energy Build. 2010;42:1582-1591. DOI: 10.1016/j.enbuild.2010.05.004.

[21] Emilsson T, Czemiel Berndtsson J, Mattsson JE, Rolf K. Effect of using conventional and controlled release fertilizer on nutrient runoff from various vegetated roof systems. Ecol Eng. 2007;29:260-271. DOI: 10.1016/j.ecoleng.2006.01.001.

[22] Kirichenko-Babko M, Łagód G, Majerek D, Franus M, Babko R. The effect of landscape on the diversity in urban green areas. Ecol Chem Eng S. 2017;24(4):613-625. DOI: 10.1515/eces-2017-0040. 
[23] Yang J, Yu Q, Gong P. Quantifying air pollution removal by green roofs in Chicago. Atmos Environ. 2008;42:7266-7273. DOI: 10.1016/j.atmosenv.2008.07.003.

[24] Van Renterghem T, Botteldooren D. In-situ measurements of sound propagating over extensive green roofs. Build Environ. 2011;46:729-738. DOI: 10.1016/j.buildenv.2010.10.006.

[25] Czemiel-Berndtsson J, Emilsson T, Bengtsson L. The influence of extensive vegetated roofs on runoff water quality. Sci Total Environ. 2006;355:48-63. DOI: 10.1016/j.scitotenv.2005.02.035.

[26] Bengtsson L, Grahn L, Olsson J. Hydrological function of a thin extensive green roof in southern Sweden. Nord Hydrol. 2005;36(3):259-268. http://hr.iwaponline.com/content/36/3/259.

[27] Getter KL, Rowe DB, Andresen JA. Quantifying the effect of slope on extensive green roof stormwater retention. Ecol Eng. 2007;31:225-231. DOI: 10.1016/j.ecoleng.2007.06.004.

[28] Mentens J, Raes D, Hermy M. Green roofs as a tool for solving the rainwater runoff problem in the urbanized 21st century? Landscape Urban Plan. 2006;77:217-226. DOI: 10.1016/j.landurbplan.2005.02.010.

[29] Young T, Cameron DD, Sorrill J, Edwards T, Phoenix GK. Importance of different components of green roof substrate on plant growth and physiological performance. Urban Forestry Urban Greening. 2014;13:507-516. DOI: 10.1016/j.ufug.2014.04.007.

[30] Farrell C, Ang XQ, Rayner JP. Water-retention additives increase plant available water in green roof substrates. Ecol Eng. 2013;52:112-118. DOI: 10.1016/j.ecoleng.2012.12.098.

[31] Hüttermann A, Orikiriza LJB, Agaba H. Application of superabsorbent polymers for improving the ecological chemistry of degraded or polluted lands. Clean - Soil Air Water. 2009;37(7):517-526. DOI: 10.1002/clen.200900048.

[32] Savi T, Marin M, Boldrin D, Incerti G, Andri S, Nardini A. Green roofs for a drier world: Effects of hydrogel amendment on substrate and plant water status. Sci Total Environ. 2014;490:467-476. DOI: 10.1016/j.scitotenv.2014.05.020. 